\title{
THE HOTHOUSE MILLIPED AS A NEW GENUS.
}

\author{
Ву O. F. Соок, \\ Custodian of Myriapoda, U. S. National Museum.
}

NOTES ON THE HABITS OF MILLIPEDS.

Most of the species of millipeds are localized in definite areas, often of very limited extent. A few species have attained a cosmopolitan distribution in the tropics, and one of these has established itself in many hothouses in Europe and America. The hothouse conditions are evidently quite congenial for this species, to judge from the abundance of individuals. They are sometimes accused of attacking the plants, though seldom convicted of any serious damage. They often feed upon tissues killed by fungi or insect pests and are likely to be looked upon as the cause of injury, instead of being recognized as harmless scavengers.

The mouthparts of millipeds are not adapted for biting or chewing, but are equipped with minute scrapers and combs for collecting soft, decaying materials. Dead or dying tissues are preferred. The only living plants that are regularly eaten by millipeds are the fleshy fungi. Some of the native millipeds in the vicinity of Washington, District of Columbia, feed to a considerable extent upon the local species of Amanita, Russula, and Lactarius. Damage is sometimes done to other plants when millipeds gain access to wounded surfaces of roots or cuttings. Healing may be prevented or cuttings may be kept from rooting by continual scraping of the exposed surfaces.

In nature at large the millipeds have a share in the beneficial work of reducing dead plant material to humus. Prussic acid and other corrosive secretions may aid in the precipitation of colloidal substances in the humus, in addition to the protection that they give by rendering the millipeds distasteful to birds and other animals that might otherwise feed upon them. The precipitation of the colloids enables the millipeds to keep their bodies clean and protects them against the clogging of their spiracles.

Proceedings U. S. National Museum, Vol. 40-No. 1842.

$80796^{\circ}$-Proc.N.M.vol 40-11-40 
In relation to the soil there is a notable contrast between the habits of millipeds in the Central American region and in West Africa. Owing, perhaps, to the great abundance of termites, the African forests have very slight superficial accumulations of dead leaves and humus. The soil remains relatively open and noncolloidal, and is inhabited by numerous species of millipeds. In the forests of tropical America the termites effect no such complete destruction of the dead leaves and other vegetable débris, which accumulate and decay on the surface. The underlying soils are generally much more colloidal than in Africa and the milliped population is generally sparse, or often lacking altogether, especially after the land has been under cultivation for a few years.

SYSTEMATIC POSITION OF THE HOTHOUSE MILLIPED.

The hothouse milliped was first described in 1847 by C. L. Koch as Fontaria gracilis, but has still to find a satisfactory place in generic classification. In addition to the original reference to Fontaria, the species figures in literature under two other generic names, Paradesmus and Orthomorpha, but none of these names seems to find a correct application to the animal in question.

In 1872 Humbert and Saussure referred Koch's species to the old genus Polydesmus, as a member of a subgenus Paradesmus, that had been established by Saussure for other species in 1859. In Latzel's monograph of the Austro-Hungarian myriapoda, published in 1884, the same course was followed, except that Paradesmus was recognized as an independent genus.

The next change was made in 1893 when Bollman discovered the preoccupation of the name Paradesmus and proposed Orthomorpha as a substitute. Hence the species has been called, by all recent writers, Orthomorpha gracilis. The unfortunate necessity of a further change arises from the fact that Bollman's new name was proposed as a direct substitute for Paradesmus, and is therefore limited in its application to the genus to which the original type of Paradesmus belongs.

\section{DESIGNATION OF THE TYPE OF PARADESMUS.}

The determination of the type of Paradesmus carries us back to the original treatment of the subgenus by Saussure. Several species were included, though none that recent authors have treated as congeneric with the hothouse milliped. Pocock has recently proposed, in the Biologia Centrali-Americana, to designate as the type of Paradesmus (and Orthomorpha), an East Indian species, O. blainvillei. This designation can hardly be accepted, in view of the fact that blainvillei was placed by Saussure in one of the two divisions of Paradesmus that were indicated as forming transitions to other sub- 
genera, and are therefore not to be reckoned as typical members of the subgenus Paradesmus. The remaining division, containing the genuine examples of Paradesmus, consisted of three species, klugii Brandt, erichsoni Brandt, and picteti Saussure. The first of these should be considered as the true type of Paradesmus, and hence of Orthomorpha as well.

The propriety of this treatment is not affected by the fact that Humbert and Saussure used the typical species of Paradesmus, ten years later, as the basis of a new subgenus, Pachyurus. Bollman found that this name also was preoccupied, and proposed to replace it by Polylepis. In reality Orthomorpha was a sufficient substitute for both Paradesmus and Pachyurus, since both these names were proposed originally for the same species.

\section{APPLICATION OF THE NAME ORTHOMORPHA.}

In view of the preceding facts, it appears that the name Orthomorpha is applicable to a Central American genus of millipeds, with O. klugii (Brandt) as the typical species, replacing Amplinus Attems, at least for the Central American species. Attems proposed this name for a subgenus of Pachyurus, with a Peruvian species, $P$. kalonotus, as the type. Pocock has adopted Amplinus as the generic name of the Central American group to which Orthomorpha klugii belongs.

ORTHOMORPHA POCOCKI, new species.

Amplinus klugi Pocock, Biol. Centr.-Amer., Diploda, p. 152, pl. 2, figs. 5c-5e, 1910. Not Polydesmus klugii Brandt, Recueil Mem. Myriop., p. 133, 1841.

The species described and illustrated as Amplinus klugi in the Biologia is not to be considered as the type of the genus Orthomorpha. The figures of the gonopods evidently do not represent the same species as Brandt's type of klugii in the Berlin Museum. The drawings show that the gonopods are relatively short and robust, with the two terminal prongs also rather short, nearly equal, and strongly incurved or connivent. In the true Orthomorpha klugii the gonopods are much longer and more tapering, with longer, more unequal, and only slightly curved prongs. Tracings of the gonopods of the type specimen of klugii at Berlin are much more similar to Pocock's figures representing Orthomorpha areata and O. favicornis than to those of $O$. pococki. The drawings of this species in the Biologia represent a specimen from Jalapa, Mexico, in the British Museum, which may be considered as the type of the new species.

The type-specimen of $O$. klugii is supposed to have been collected by Deppe at Alvarado, in the State of Vera Cruz. Four other species of Orthomorpha are known from Mexico, O. palicaudatus (Attems), O. erichsonii (Brandt), O. armatus (Pocock), and O. triramus (Pocock). Three species are credited to Guatemala, O. nitidus (Broelemann), 
O. palicaudatus (Attems), and O. areatus (Pocock). Other Central American countries are not yet represented in the genus Orthomorpha, except Costa Rica, with a single species, O. convexus (Carl).

Pocock's suggestion that $O$. erichsonii is probably a synonym of O. klugii is unfortunate. A comparison of the types of the two species at Berlin showed that the gonopods were very different, those of $O$. erichsonii having three prongs, somewhat as in $O$. triramus, but considerably longer and more nearly equal and parallel.

Saussure's Polydesmus picteti, the third of the species originally referred by that author to the typical section of his subgenus Paradesmus, is also placed by Pocock as a synonym of klugii, but may prove to be a distinct species.

\section{A NEW GENERIC NAME FOR THE HOTHOUSE MILLIPED.}

The complications that attend the application of the generic name Orthomorpha to Central American species should not affect the status of the hothouse milliped. None of the previously applied generic names being available, this species remains to be treated as the type of a new genus, for which the name Oxidus is proposed, in allusion to the repugnatorial secretion of prussic acid. This milliped served as the basis of the first chemical investigation of the nature of the secretion.

Although the animal is perhaps the most common and widely distributed representative of the whole class Diplopoda, several characters available for generic diagnosis seem to have been overlooked.

\section{OXIDUS, new genus.}

Genotype.-Fontaria gracilis C. L. Koch, a species widely distributed in the tropics and in hothouses. First described from a hothouse in Austria. Original habitat unknown, but supposed to be in the East Indies. Present description based on specimens collected in greenhouses of the Bureau of Plant Industry, U. S. Department of Agriculture, Cat. No. 810, U.S.N.M.

Diagnosis.-Antennæ inserted low down and close together; first segment enlarged, second and third segments reduced; posterior subsegments crossed by a deep transverse impression; constriction between the subsegments deep and strongly beaded; lateral carinæ strongly margined with a prominent setiferous tubercle near the anterior corner; repugnatorial pores distinctly lateral, behind the middle of the segments, with distinct raised rims; posterior segments scarcely shortened; last segment with two transverse rows of setiferous tubercles, the apex with two large rounded, nonsetiferous tubercles; sterna with median and transverse impressions and a broadly conic tubercle at the base of each leg; spiracles with expanded 
auriculate rims; legs of males tuberculate on the lower surfaces of the last two joints; gonopods with second joint robust, ending in four strongly curved simple prongs.

Description.-Body small and depressed, oblong, slender, over eight times as long as wide.

Head strongly convex, prominënt; vertex evenly rounded, smooth, with a deep median furrow to near the level of the antennæ; a few setiferous punctations on each side of the furrow; hirsute between and below the antennæ, also punctate and transversely rugulose; labrum with three distinct teeth in a shallow emargination, bordered by two regular rows of setiferous punctations.

Antennæ inserted low down, separated by only about the width of one of the sockets; rather slender filiform, or the terminal joints slightly thicker, joints $2-6$ nearly equal in length.

First segment somewhat wider than the head, transversely oblong, over twice as broad as long, anterior and posterior corners rounded, especially the former; anterior margin with a fine raised rim, broader and more prominent on the sides; surface evenly convex, with a transverse row of ten setiferous punctations near the anterior margin and a second row of two punctations a little behind the middle. Lateral punctations of anterior row mounted on the raised margin.

Segments 2 and 3 much shorter than the others, only about half as long as segment 1; lateral carinæ of segment 2 depressed below the level of the others and prolonged in front under the posterior corners of segment 1. Segment 4 intermediate in length between 3 and 5 and with a transverse dorsal impression wanting on segments 2 and 3.

Subsequent segments with dorsal surface nearly smooth, somewhat rugulose and very minutely striolate longitudinally, under sufficient magnification; marked with a slight median impression and a deep transverse furrow across the middle of the posterior subsegments. Each segment with a transverse row of six bristles near the anterior margin, the lateral pair of bristles on the raised rims of the carinæ.

Lateral carinæ nearly horizontal, rather narrow, less than onefourth as wide as the body cavity, with distinct raised margins; anterior corners rounded, the posterior nearly a right angle on anterior segments, becoming more produced and somewhat spiniform on posterior segments; lateral edge of carinæ nearly straight, but abruptly narrowed behind a setiferous tubercle near the anterior corner.

Repugnatorial pores inserted in small lateral excavations of segments, 5, 7, 9, 10, 12, 13, 15-19; margins of poriferous carinæ somewhat thickened, especially underneath the pores, but the pores not indicated from above, except that the lateral margin is usually distinctly sinuate above the pore. 
Anterior subsegments covered with a rather regular minute reticulation of raised lines; separated from the posterior subsegment by a very deep, abrupt, and distinctly beaded transverse constriction. Reticulation interrupted a little in front of the constriction by a delicate transverse impressed line.

Pleuræ roughened with scattered granules, thickened below into an oblique ridge, sharply angled behind, especially on anterior segments.

Penultimate segment scarcely shortened, but the carinæ distinctly smaller and less acutely produced; not transversely impressed like the preceding segments, but with a pair of bristles on the posterior part of the segment in addition to the six anterior bristles.

Last segment nearly twice as long as the exposed part of the penultimate, the projecting apex rather large, about as long as broad, ending in a pair of prominent rounded, nonsetiferous tubercles separated by a distinct notch with two pairs of setiferous punctations. A transverse row of four bristles in front of the apex, one pair dorsal, the other lateral, another transverse row of eight bristles near the middle of the segment, two pairs dorsal and two pairs lateral, near the upper corners of the anal valves.

Anal valves rather flat, but distinctly convex in the middle, with distinctly compressed raised margins; two setiferous tubercles distinct from the margins. Preanal scale nearly as long as broad, convex, distinctly angled by the prominent setiferous tubercles that equal or exceed the scarcely produced apex.

Sterna smooth, rather sparsely hirsute, with a distinct but gradually sloping cruciform impression; a small broadly conic tubercle or spine at the base of each leg, directed caudad. Spiracles with large ear-like expanded rims on the outer side, especially the anterior pair of each segment. Coalesced pleuræ of second segment of male with a median process in front and behind; those of the third segment of the female with a median process in front.

Legs of moderate length, rather robust; joints 3 and 6 the longest, subequal, all the joints moderately hirsute, at least on the ventral surface; joints 5 and 6 also tuberculate on the ventral surface in the male, but not provided with cushions of dense hairs. Seminal ducts opening in small pores on the rounded mesial corners of tha basal joints of the second pair of legs.

Gonopods rather short, accommodated by a slight excavation between the bases of the seventh pair of legs; aperture without a raised rim; basal joint prominent; apical joint with a very short, cushion-like hirsute base, a robust, obconic slightly curved shaft, and four terminal curved prongs, a short one projecting mesad, and two much larger projecting distad, but strongly incurved and decurved; the shorter of the two rises from a slender base and expands into a thin oblique, triangular decurved blade; the longer prong rises from a rather broad, 
tapering base, curves around the more slender prong and ends in two diverging plates. The fourth prong, carrying the seminal duct, is simple and very slender. It rises from the anterior or dorsal face of the shaft, curves abruptly forward, enters the base of the third prong, and remains inclosed for nearly its entire length, only the tip emerging at the side of the proximal plate of the third prong.

The general form of the gonopods is fairly well shown in Latzel's figure, though somewhat conventionalized, except for the treatment of the third prong that sheaths the seminal duct. The sheath is formed by infolding of the edges along the convex outer margin, which appears completely closed in Latzel's figure.

\section{OXIDUS GRACILIS (C. L. Koch).}

Fontaria gracilis C. L. Косн, System der Myriopoden, p. 142, 1847; Die Myriopoden, vol. 2, p. 51, pl. 85, fig. 173, 1863.

Paradesmus gracilis Latzes, Myr. der Oest.-Ung. Mon., vol. 2, p. 162, pl. 6, fig. 70, 1884.

Paradesmus dasys Bolmann, Proc. U. S. Nat. Mus., vol. 10, p. 619, 1887.

Orthomorpha gracilis Bolmann, Bull. 46, U. S. Nat. Mus., p. 197, 1893.-Pocock, Ann. Mag. Nat. Hist., ser. 6, vol. 15, p. 354, 1895.-Aтrems, Denkschr. kais. Acad. Wiss., Wien, vol. 47, p. 337, 1898.-Pocock, Biol. Centr.-Amer., Diplopoda, p. 160, 1909 .

Length of males $19.21 \mathrm{~mm}$., width $2.2 \mathrm{~mm}$.; females $20-22 \mathrm{~mm}$. by $2.5 \mathrm{~mm}$.

Living colors of adult: Dorsum deep chestnut brown or black, the carinw bordered with lemon yellow, the sides chestnut brown, sterna and basal joints of legs pallid; distal joints of legs and apex of last segment of body rather pale, but distinctly tinged with brown; antennæ and vertex dark brown, darker than other parts of the head. Young individuals are paler brown and lack the yellow color of the carinæ. The yellow also disappears in alcohol, leaving the carinæ pale like the ventral surfaces. In some specimens the carine of the second segment are much darker than the others.

The three characters used by Bollman in the diagnosis of Paradesmus dasys, the tubercles of the legs of males, the hairs of the vertex, and the two rows of bristles on the first and penultimate segments, are present, apparently, in all specimens of gracilis. The fact that they had been overlooked by previous writers seems to have been the occasion of the naming of the new species. 


\section{$2 \mathrm{BHL}$ Biodiversity Heritage Library}

Cook, O. F. 1911. "The hothouse milliped as a new genus." Proceedings of the United States National Museum 40(1842), 625-631.

https://doi.org/10.5479/si.00963801.40-1842.625.

View This Item Online: https://www.biodiversitylibrary.org/item/53820

DOI: https://doi.org/10.5479/si.00963801.40-1842.625

Permalink: https://www.biodiversitylibrary.org/partpdf/53299

\section{Holding Institution}

Smithsonian Libraries

\section{Sponsored by}

Smithsonian

\section{Copyright \& Reuse}

Copyright Status: Public domain. The BHL considers that this work is no longer under copyright protection.

This document was created from content at the Biodiversity Heritage Library, the world's largest open access digital library for biodiversity literature and archives. Visit BHL at https://www.biodiversitylibrary.org. 